\title{
Laser Beam Surface Pretreatment for the Adhesive Bond Strength Improvement
}

\section{B. Ciecińska}

Rzeszów University of Technology, Rzeszów, Poland

Adhesive bonding is one of many operations in the manufacturing process that requires special methods of the surface pretreatment. In adhesive bonding, adhesion strength plays a crucial part in the contact of two bodies. For the improvement of this property and preparation of the surface of adequate quality, degreasing, sand blasting, grinding, and a galvanic bath are often used. These methods pose some problems. The condition of the surface may be unstable and the baths are not friendly to the human and natural environment due to the presence of tetraoxochromates, phosphates or fluorides. The laser treatment of the surface before adhesive bonding is described. After that the surface acquired a specific shape and as a result, the strength of adhesive bonds was improved. The results of the laser beam treatment may be different for various materials. The treatment results for chosen specimens in comparison which traditional preparation are shown. The examples of obtained bond strength values are presented.

Keywords: laser treatment, surface, strength, adhesive bonding.

Introduction. Adhesive bonding is a well-accepted and readily available method of joining parts due to its indisputable advantages. Bonded structures may be more lightweight, e.g., in aircrafts, due to lack of fasteners and exhibit higher damage resistance. The structures may also acquire much higher aerodynamic properties [1]. Adhesive bonding is a method of joining parts made of the materials, which are impossible to join by other methods, like welding, soldering or riveting [2-5]. On the other hand, adhesive bonding is widely used for joining different materials, like metal, rubber, glass, and ceramics. Sometimes an adhesive layer works as a vibration damper and a seal or insulator $[6,7]$. Adhesive bonding is much used in joining both small and large structures, of simple and irregular shapes, bodies or equipment, etc. [8,9].

1. Theoretical. There exist several theories that describe the conditions providing the effective adhesion. One of them is mechanical theory that treats the specific roughness of the surface. The surface of the two bodies should be porous, rough, susceptible to mechanical "anchorage" of the adhesive. The proper surface treatment before bonding would require machining to achieve the highest density of cavities and protrusions. As a result, the penetration of an adhesive into these cavities is improved, and the joint strength can be enhanced. However, the risk of imperfect penetration is still run (Fig. 1) [8, $10]$.

2. Experimental. The following specimens were prepared to be used in experimental studies and comparative analysis of improving the static strength: A - X6Cr17 steel - used as a corrosion-resistant material, hard-to-weld, B - AISI 4130 steel - well-accepted in many structures, C - 2024 aluminum alloy - used among others, in aircraft structures, and D 5083 aluminum alloy - as above. The composition of these materials is shown in Table 1.

From the rolled sheets of each material $1-\mathrm{mm}$-thick, $25 \times 100 \mathrm{~mm}$, specimens were prepared. After proper surface treatment single lap joints were bonded with an Araldite 2011 epoxide adhesive (Fig. 2). Each option was repeated five times.

The preparation of each surface was as follows:

(i) steels (X6Cr17 and AISI 4130) - typical: grinding, cleaning in acetone, drying, and laser treatment as an alternative method;

(ii) aluminum alloys (2024 and 5083) - typical: after a galvanic bath and laser treatment as an alternative method. 
$\mathrm{T}$ a b 1 e 1

Elements of the Materials Used in the Experiment [12] (Mass Concentration, \%)

\begin{tabular}{|c|c|c|c|c|c|c|c|c|c|c|c|c|}
\hline \multicolumn{13}{|c|}{$\mathrm{X} 6 \mathrm{Cr} 17$ steel } \\
\hline $\mathrm{C}$ & $\mathrm{Mn}$ & $\mathrm{Si}$ & $\mathrm{P}$ & $\mathrm{S}$ & $\mathrm{Cr}$ & $\mathrm{Ni}$ & Mo & $\mathrm{V}$ & $\mathrm{W}$ & $\mathrm{Ti}$ & $\mathrm{Cu}$ & As \\
\hline$\leq 0.08$ & $\leq 1.00$ & $\leq 1.00$ & $\leq 0.04$ & $\leq 0.015$ & $\begin{array}{c}16.0- \\
18.0\end{array}$ & - & - & - & - & - & - & - \\
\hline \multicolumn{13}{|c|}{ AISI 4130 steel } \\
\hline $\begin{array}{c}0.22- \\
0.29\end{array}$ & $\begin{array}{c}0.4- \\
0.7\end{array}$ & $\begin{array}{c}0.17- \\
0.37\end{array}$ & $\leq 0.035$ & $\leq 0.035$ & $\begin{array}{c}0.8- \\
1.1\end{array}$ & $\leq 0.3$ & $\begin{array}{c}0.15- \\
0.25\end{array}$ & $\leq 0.05$ & $\leq 0.20$ & $\leq 0.05$ & $\leq 0.25$ & $\leq 0.08$ \\
\hline \multicolumn{13}{|c|}{2024 aluminum alloy } \\
\hline $\mathrm{Si}$ & $\mathrm{Fe}$ & $\mathrm{Cu}$ & $\mathrm{Mn}$ & $\mathrm{Mg}$ & $\mathrm{Cr}$ & $\mathrm{Ni}$ & $\mathrm{Zn}$ & $\mathrm{V}$ & $\mathrm{Ti}$ & $\mathrm{Al}$ & \multicolumn{2}{|c|}{ other } \\
\hline$\leq 0.20$ & $\leq 0.50$ & $\begin{array}{c}3.5- \\
4.9\end{array}$ & $\begin{array}{c}0.3- \\
0.9\end{array}$ & $\begin{array}{c}1.2- \\
1.8\end{array}$ & $\leq 0.10$ & - & $\leq 0.25$ & - & $\leq 0.15$ & rest & \multicolumn{2}{|c|}{$\leq 0.15$} \\
\hline \multicolumn{13}{|c|}{5083 aluminum alloy } \\
\hline$\leq 0.40$ & $\leq 0.40$ & $\leq 0.10$ & $\begin{array}{c}0.4- \\
1.0\end{array}$ & $\begin{array}{c}4.0- \\
4.9\end{array}$ & $\begin{array}{c}0.05- \\
0.25\end{array}$ & - & $\leq 0.25$ & - & $\leq 0.15$ & rest & \multicolumn{2}{|c|}{$\leq 0.15$} \\
\hline
\end{tabular}

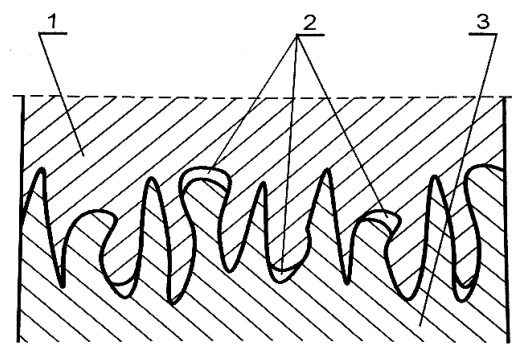

Fig. 1. Scheme of mechanical adhesion: $(1,3)$ bonded parts, (2) cavities [11].

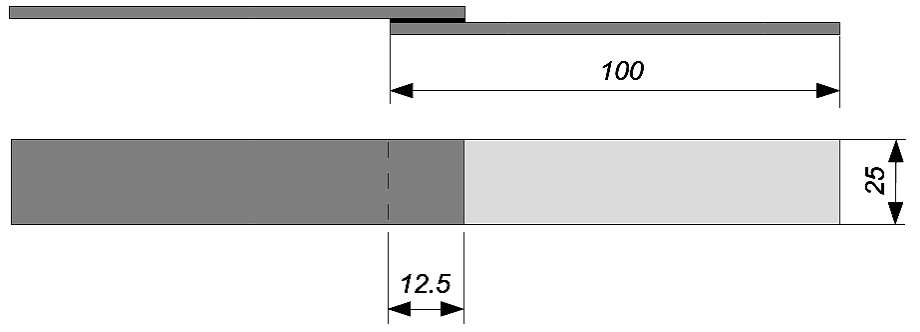

Fig. 2. Adhesive joint prepared for the experiment.

The laser treatment was proposed as an alternative method. Experimental studies make use of a mobile laser system, consisting of a generator and head connected with the optical fiber cable and industrial air filter (Fig. 3a). For enhancing the adhesive bonding, laser beam paths were specially arranged. The beam paths were normal to the specimen surface, and their interval was dependent on the specimen motion relative to the beam path. The scanning speed had four options, viz. 115, 175, 250, and $375 \mathrm{~mm} / \mathrm{min}$. The operation was realized on the table of a conventional machine tool (Fig. 3b, c). The specimens were treated with the laser beam of the following parameters: $100 \%$ power $(500-\mathrm{W}$ head), $50-\mathrm{Hz}$ frequency, and $150-\mathrm{mm} / \mathrm{s}$ scanning speed. 


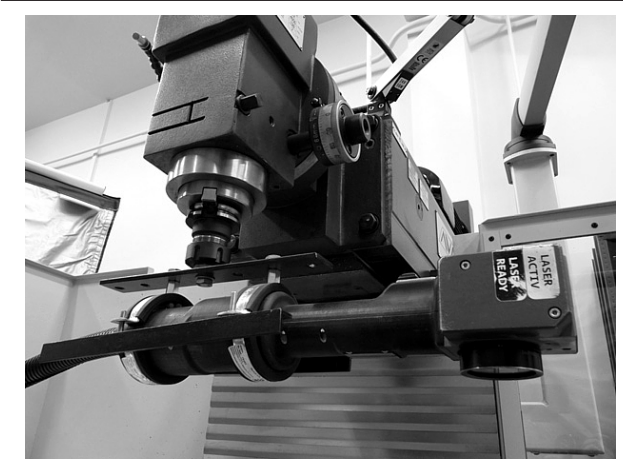

a

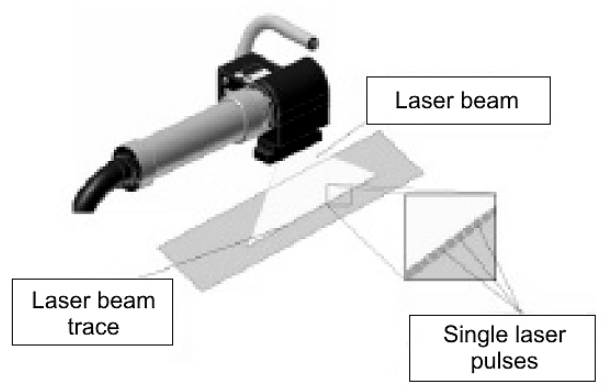

b

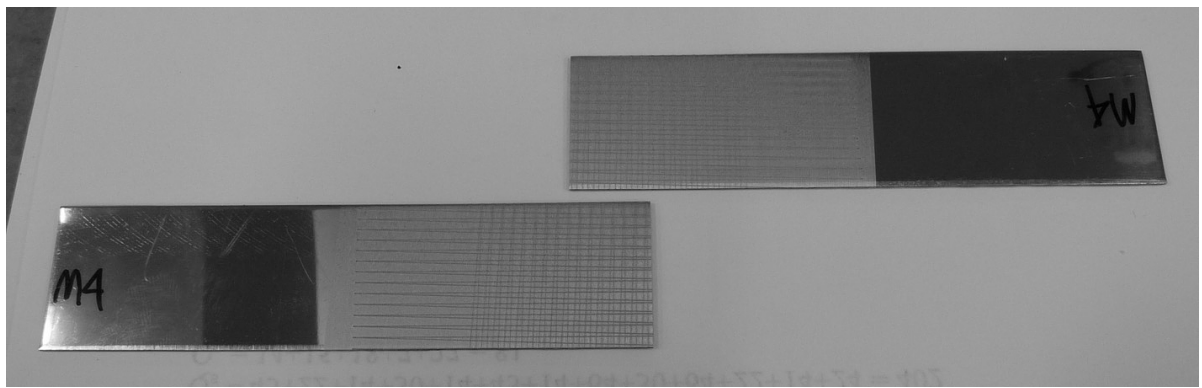

c

Fig. 3. Mobile laser system in the experiment: (a) head; (b) scheme of a laser beam path; (c) specimens with the mutually perpendicular beam paths.

3. Results. The specimens were loaded on a ZWICK-ROELL tensile testing machine with the initial speed of $2 \mathrm{~mm} / \mathrm{min}$. The load reached in the tests was assessed against the lap size of $12.5 \times 25 \mathrm{~mm}\left(312.5 \mathrm{~mm}^{2}\right)$, and the static strength was calculated as the load divided by the lap area. Test and calculation results are summarized in Tables 2-5.

Comparative analysis of the results is presented in Fig. 4.

$\mathrm{T}$ a b 1 e 2

Static Strength of X6Cr17 Steel + 2011 Araldite Adhesive Bonds

\begin{tabular}{|c|c|c|c|c|c||}
\hline \multirow{2}{*}{$\begin{array}{c}\text { No. } \\
\text { of specimen }\end{array}$} & \multirow{2}{*}{$\begin{array}{c}\text { Load (N) } \\
\text { after sand } \\
\text { blasting } \\
\text { (option 1) }\end{array}$} & $\begin{array}{c}115 \mathrm{~mm} / \mathrm{min} \\
\text { (option 2) }\end{array}$ & $\begin{array}{c}175 \mathrm{~mm} / \mathrm{min} \\
\text { (option 3) }\end{array}$ & $\begin{array}{c}250 \mathrm{~mm} / \mathrm{min} \\
\text { (option 4) }\end{array}$ & $\begin{array}{c}375 \mathrm{~mm} / \mathrm{min} \\
\text { (option 5) }\end{array}$ \\
\cline { 3 - 6 } & 4787.8 & 6117.8 & 6558.9 & 6520.6 & 5028.5 \\
\hline 1 & 4778.7 & 6140.2 & 7554.8 & 6528.1 & 5675.6 \\
\hline 3 & 4956.9 & 5979.1 & 6893.6 & 6787.5 & 6117.0 \\
\hline 4 & 4729.2 & 6134.2 & 6202.1 & 6720.4 & 5679.2 \\
\hline 5 & 4665.5 & 6526.4 & 6933.4 & 6619.9 & 5988.5 \\
\hline $\begin{array}{c}\text { Arithmetic } \\
\text { mean (N) }\end{array}$ & 4783.6 & 6179.5 & 6828.6 & 6635.3 & 5697.8 \\
\hline $\begin{array}{c}\text { Static strength } \\
\text { (MPa) }\end{array}$ & 15.31 & 19.77 & 21.85 & 21.23 & 18.23 \\
\hline
\end{tabular}


T a b 1 e 3

Static Strength of AISI 4130 Steel + 2011 Araldite Adhesive Bonds

\begin{tabular}{||c|c|c|c|c|c||}
\hline \multirow{2}{*}{$\begin{array}{c}\text { No. } \\
\text { of specimen }\end{array}$} & \multirow{2}{*}{$\begin{array}{c}\text { Load (N) } \\
\text { after sand } \\
\text { blasting } \\
\text { (option 1) }\end{array}$} & $\begin{array}{c}\text { Load (N) after laser treatment } \\
\text { (option 2) }\end{array}$ & $\begin{array}{c}175 \mathrm{~mm} / \mathrm{min} \\
\text { (option 3) }\end{array}$ & $\begin{array}{c}250 \mathrm{~mm} / \mathrm{min} \\
\text { (option 4) }\end{array}$ & $\begin{array}{c}375 \mathrm{~mm} / \mathrm{min} \\
\text { (option 5) }\end{array}$ \\
\hline 1 & 5041.4 & 5882.2 & 5751.1 & 5310.0 & 5205.3 \\
\hline 2 & 5383.0 & 5798.2 & 5113.5 & 5351.0 & 4822.8 \\
\hline 3 & 5646.7 & 5754.2 & 5251.5 & 5192.3 & 5325.5 \\
\hline 4 & 5353.5 & 6068.3 & 5250.5 & 5469.2 & 4972.1 \\
\hline 5 & 5405.2 & 4770.0 & 5175.7 & 5812.2 & 5328.2 \\
\hline $\begin{array}{c}\text { Arithmetic } \\
\text { mean (N) }\end{array}$ & 5366.0 & 5654.6 & 5308.5 & 5426.9 & 5130.8 \\
\hline $\begin{array}{c}\text { Static strength } \\
(\mathrm{MPa})\end{array}$ & 17.17 & 18.09 & 16.99 & 17.37 & 16.42 \\
\hline
\end{tabular}

T a b 1 e 4

Static Strength of 2024 Aluminum Alloy +2011 Araldite Adhesive Bonds

\begin{tabular}{||c|c|c|c|c|c||}
\hline \multirow{2}{*}{$\begin{array}{c}\text { No. } \\
\text { of specimen }\end{array}$} & $\begin{array}{c}\text { Load (N) } \\
\text { after galvanic } \\
\text { bath } \\
\text { (option 1) }\end{array}$ & $\begin{array}{c}115 \mathrm{~mm} / \mathrm{min} \\
\text { (option 2) }\end{array}$ & $\begin{array}{c}175 \mathrm{~mm} / \mathrm{min} \\
\text { (option 3) }\end{array}$ & $\begin{array}{c}250 \mathrm{~mm} / \mathrm{min} \\
\text { (option 4) }\end{array}$ & $\begin{array}{c}375 \mathrm{~mm} / \mathrm{min} \\
\text { (option 5) }\end{array}$ \\
\cline { 5 - 6 } & 2977.4 & 8031.5 & 4450.0 & 6138.8 & 4298.0 \\
\hline 1 & 4653.2 & 7862.7 & 4685.0 & 4835.0 & 4165.6 \\
\hline 3 & 3341.8 & 7288.5 & 7005.7 & 4956.2 & 3138.0 \\
\hline 4 & 3768.6 & 7751.3 & 5764.4 & 4916.4 & 6144.6 \\
\hline 5 & 2986.5 & 7100.8 & 5765.2 & 6023.9 & 5232.8 \\
\hline $\begin{array}{c}\text { Arithmetic } \\
\text { mean (N) }\end{array}$ & 3545.5 & 7607.0 & 5534.1 & 5374.1 & 4595.8 \\
\hline $\begin{array}{c}\text { Static strength } \\
\text { (MPa) }\end{array}$ & 11.35 & 24.34 & 17.71 & 17.20 & 14.71 \\
\hline
\end{tabular}

T a b 1 e 5

Static Strength of 5083 Aluminum Alloy + 2011 Araldite Adhesive Bonds

\begin{tabular}{||c|c|c|c|c|c||}
\hline \multirow{2}{*}{$\begin{array}{c}\text { No. } \\
\text { of specimen }\end{array}$} & $\begin{array}{c}\text { Load (N) } \\
\text { after galvanic } \\
\text { bath } \\
\text { (option 1) }\end{array}$ & $\begin{array}{c}115 \mathrm{~mm} / \mathrm{min} \\
\text { (option 2) }\end{array}$ & $\begin{array}{c}175 \mathrm{~mm} / \mathrm{min} \\
\text { (option 3) }\end{array}$ & $\begin{array}{c}250 \mathrm{~mm} / \mathrm{min} \\
\text { (option 4) }\end{array}$ & $\begin{array}{c}375 \mathrm{~mm} / \mathrm{min} \\
\text { (option 5) }\end{array}$ \\
\cline { 4 - 6 } & 4002.7 & 4707.9 & 4045.3 & 3614.7 & 3631.7 \\
\hline 2 & 3972.7 & 4637.7 & 4428.4 & 3576.2 & 3778.6 \\
\hline 3 & 3705.0 & 4844.4 & 4006.9 & 3594.5 & 3413.4 \\
\hline 4 & 3820.6 & 4702.3 & 4179.3 & 3513.3 & 3739.2 \\
\hline 5 & 3581.2 & 4821.4 & 4217.7 & 3702.4 & 3352.6 \\
\hline $\begin{array}{c}\text { Arithmetic } \\
\text { mean (N) }\end{array}$ & 3816.4 & 4742.7 & 4175.5 & 3600.2 & 3581.1 \\
\hline $\begin{array}{c}\text { Static strength } \\
(\mathrm{MPa})\end{array}$ & 12.21 & 15.18 & 13.36 & 11.52 & 11.47 \\
\hline
\end{tabular}


$\mathrm{X} 6 \mathrm{Cr} 17$

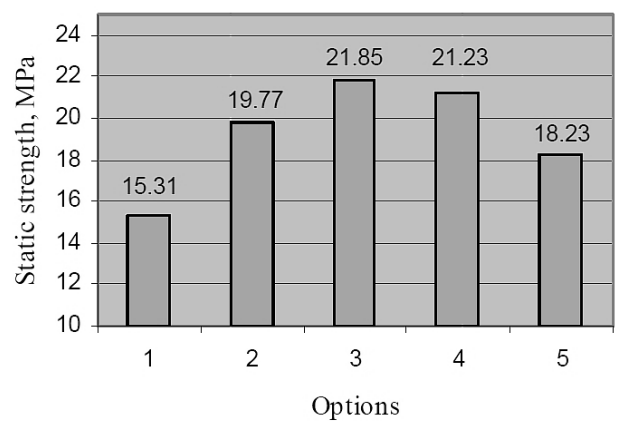

a

2024

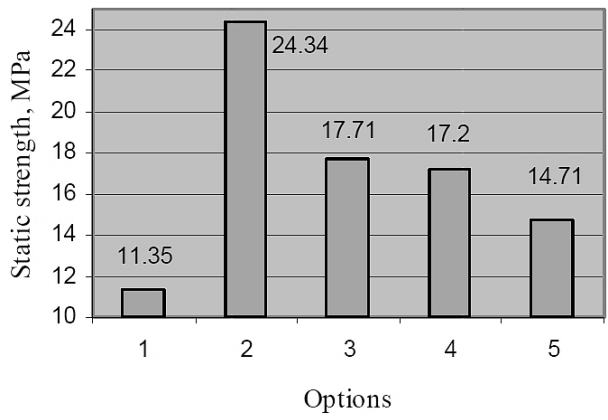

c
AISI 4130

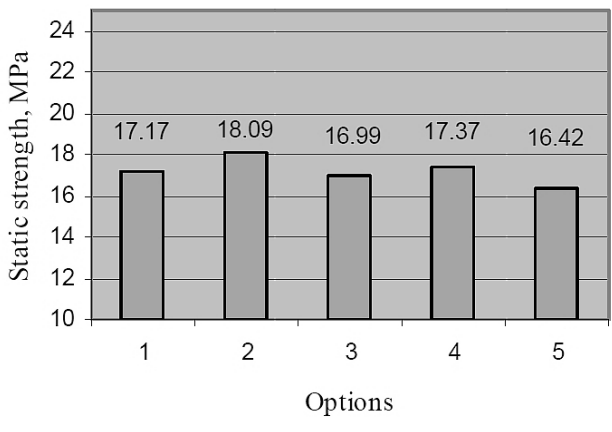

b

5083

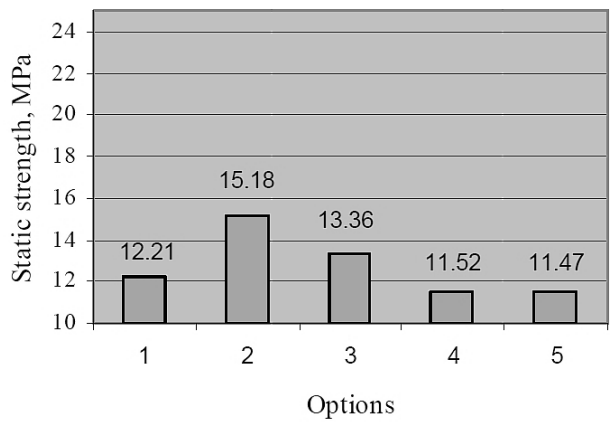

d

Fig. 4. Static strength assessment results for steels: (a) X6Cr17, (b) AISI 4130, and aluminum alloys: (c) 2024, (d) 5083 .

Conclusions. The results show that laser beam treatment may be a useful technique for the surface preparation prior to adhesive bonding. Static strength values after laser beam treatment (2-5) are higher than those after the use of traditional methods. For X6Cr17 steel the strength improvement is visible. The best results are observed for options 3 and 4 $(21.85$ and $21.23 \mathrm{MPa}$ ), in this case, the strength is enhanced by about $43 \%$. For AISI 4130 steel the situation is different, viz all values are similar, but it means that a traditional chemical-based method may be replaced by the new one without the loss of strength. For a 2024 aluminum alloy an increase in strength was more than twice (from 11.35 to $24.34 \mathrm{MPa}$ ) or at least by about $56 \%$ in options 3 and 4 (about $17 \mathrm{MPa}$ ). For a 5083 aluminum alloy the strength improvement was not so pronounced, but the best value $(15.18 \mathrm{MPa})$ is higher than after a galvanic bath (by about $25 \%$ ). The data are very promising and suggest that in the future laser treatment would replace traditional methods based on chemicals or other techniques that are not friendly to human and environment. Different results demonstrating an increase in strength should create the grounds for experimental studies to establish the process conditions for structural materials.

1. J. Godzimirski, Tworzywa Adhezyjne. Zastosowanie w Naprawach Sprzętu Technicznego, Wydawnictwo Naukowo-Techniczne, Warszawa (2010).

2. E. M. Petrie, "Adhesives for the assembly of aircraft structures and components: decades of performance improvement, with the new applications of the horizon," Met. Finish., 106, No. 2, 26-31 (2008). 
3. G. Habenicht, Applied Adhesive Bonding: A Practical Guide for Flawless Results, Wiley-VCH Verlag GmbH \& Co. KGaA, Weinheim (2009).

4. B. Bartczak, J. Mucha, and T. Trzepieciński, "Stress distribution in adhesively-bonded joints and the loading capacity of hybrid joints of car body steels for the automotive industry," Int. J. Adhes. Adhes., 45, 42-52 (2013).

5. J. Mucha and W. Witkowski, "Mechanical behavior and failure of riveting joints in tensile and shear tests," Strength Mater., 47, No. 5, 755-769 (2015).

6. J. Godzimirski, "Problemy klejenia konstrukcyjnego," Technologia i Automatyzacja Montażu, No. 1, 25-31 (2009).

7. A. Rudawska and M. Chruściel, "Wpływ sposobu przygotowania powierzchni na wytrzymałość połączeń klejowych lotniczego stopu aluminium," Technologia $i$ Automatyzacja Montażu, No. 2, 42-46 (2011).

8. J. Kuczmaszewski, Fundamentals of Metal-Metal Adhesive Joint Design, WSCHÓD Agencja Usługowa, Lublin (2006).

9. Z. Wiącek, Badania Wpływu Stanu Powierzchni Metali Lekkich na Jakość Połaczeń Adhezyjnych, Wydawnictwa Uczelniane Politechniki Lubelskiej, Lublin (1987).

10. A. Higgins, "Adhesive bonding of aircraft structures," Int. J. Adhes. Adhes., 20, 367$376(2000)$.

11. J. Kuczmaszewski, Podstawy Konstrukcyjne i Technologiczne Oceny Wytrzymatości Adhezyjnych Połaczeń Metali, Wydawnictwo Uczelniane Politechniki Lubelskiej, Lublin (1995).

12. L. Dobrzanski (Red.), Zasady Doboru Materiałów Inżynierskich z Kartami Charakterystyk, Wydawnictwo Politechniki Śląskiej, Gliwice (2002).

Received 10. 08. 2016 